\title{
Högskolan är inte ett företag, studenter inte dess kunder och konkurrens inte dess drivkraft
}

Under denna princip ifrågasätter jag de gynnsamma effekterna för individen och för samhället som helhet av en marknadifiering och konkurrensutsättning av högskolesystemet. Förlorarna, i form av lärosäten och studenter, kanske lider större förluster än som kan vägas upp av vinsterna för vinnarna.

\section{Högskoleindustri vs skapande intellekt}

Denna princip låter onekligen negativ: tre negationer i samma mening. Men företaget på den konkurrensutsatta marknaden är så viktigt, för att inte säga allenarådande, som sinnebild för ett välfungerande, effektivt samhällsystem att det krävs en hel del ifrågasättande. Sverige har idag kanske ett av världens mest marknadsutsatta system för ungdomsskolan. Visserligen är marknaden artificiell, eftersom den skapats enbart av skattepengar, men på ett annat sätt är den reell och kan skapa betydande vinster för de riskkapitalbolag som allt oftare står bakom Sveriges så kallade friskolor. Att begrunda vad de skulle vara fria ifrån, och vilka andra tvång de lyder under, förtjänar en egen utredning.

Högskolorna släpptes dock fria - fria, förstås, endast i den här mycket speciella betydelsen - redan 1993. En långt driven central regelstyrning ersattes också här av en fingerad marknad där varje student som antas till en utbildning

How to cite this book chapter:

Casson, A 2015 Högskolans ansvar: Principer för utveckling av den högre utbildningen.

London: Ubiquity Press. DOI: http://dx.doi.org/10.5334/bap.l License: CC-BY 3.0 
tar med sig en tämligen rejäl slant från det allmänna. Skillnaden är dock att det ännu inte släppts in några privata, vinstdrivande företag på högskolemarknaden. Det finns förvisso idag tre stiftelsehögskolor i Sverige men skillnaderna i hur de drivs och styrs jämfört med de statliga myndighetshögskolorna har visat sig bli små, eftersom de måste följa nästan exakt samma planering och reglering för att få ut sina studentpengar. Skillnaderna kommer att komma den dagen studieavgifter införs inte bara för fristående kurser, vilket mycket väl kan hända inom några år, utan även för de stora programutbildningarna. Om staten samtidigt släpper sitt monopol som huvudman för högskolorna, kommer Sverige att se en utveckling som till vissa delar påminner om hur det ser ut i USA idag. England har varit ett föregångsland för svenska politiker och de tycks följa efter engelska reformer inom styrning och marknadifiering av högskolorna med ungefär tio års eftersläpning. Där har man infört studieavgifter om uppemot 100000 konor per år och den statliga finansieringen av högskolorna ligger nu långt under hälften av deras totala intäkter.

USA har mera sällan varit en förebild för det svenska utbildningssystemet, även om många ledande svenska forskare varit där en tid och suckar längtansfullt efter vackra campus, det otvungna umgänget och koffertar välfyllda med donationsmedel. Skillnaderna är helt enkelt för stora. USA har däremot varit en oerhört viktig förebild för resten av världen. När inte minst nyrika länder har velat bygga upp ett högskolesystem i världsklass och excellent forskning från scratch har man rekryterat amerikanska toppforskare för att bygga upp framstående miljöer enligt amerikansk modell. De senaste åren har just de två orden - världsklass och excellent - dykt upp allt oftare i politikers tal, på forskningsstiftelsers konferenser och i svenska lärosätens policydokument. Det speglar en global högskolediskurs där konkurrens är den obestridda drivkraften. När ett av världens högst rankade universitet, Harvard, erbjuder en tvådagarskurs om trender och tendenser i den högre utbildningen, är det under rubriken "Strategi och konkurrens i högre utbildning"162 och i prospektet skriver man inledningsvis att hela "högskoleindustrin" är mitt uppe i en viktig dynamisk förändringsprocess. Senare slopar man citattecknen.

Vilka är förändringarna som Harvardkursen ser i det amerikanska och globala utbildningslandskapet? Det blir flera program, skriver de, som ger en mera omedelbar utdelning i form av jobb och lön för den ska återbetala sina studielån och för en arbetsmarknad som ropar efter kompetens. De ser ökande kostnader och minskande budgetar, snabb tillväxt av online-utbildning, en

162 "The higher education 'industry' is in the midst of significant, dynamic change. A multitude of factors-the proliferation of programs, increasing costs, shrinking budgets, growth of online education, explosion of educational content, rise of new competitors, and the advent of new business models-have combined to fundamentally alter the competitive terrain for colleges and universities, and the organizations that work with them." http://www.dce.harvard.edu/ professional/programs/strategy-competition-higher-education.jsp;jsessionid=OJGCKPIFLCHH, hämtad 2013-03-10 ur Harvard Extension School's kursprospekt för 2-dagarskursen Strategy and Competition in HE med studieavgift 2200 USD. 
explosion i utbildningsstoff, nya konkurrenter, nya affärsmodeller. Allt detta har lett till grundläggande förändringar i högskolesystemets konkurrenslandskap. I en annan framställning pekar man på den globala jakten efter de bästa studenterna och forskarna, mätt efter mått som Nobelpris, publicering i högst rankade tidskrifter och så vidare, för att skapa universitet i världsklass. Allteftersom insikten växer att humankapital är nyckeln till innovation och tillväxt, välkomnas alltfler offshorefilialer från erkända varumärken inom den globala universitetsindustrin till ambitiösa nationer som här ser en genväg till excellens. Både i USA och andra delar av världen växer antalet och volymen på vinstdrivande högskolor, inte minst de med mycket utbildning på nätet, Kaplan till exempel, eller University of Phoenix med sin kvartsmiljon studenter och 20000 personal.

80 år tidigare, vid samma Harvard, fanns en annan syn på universitetet och dess roller. Den brittiska matematikern och filosofen Alfred North Whitehead, som verkade där under senare delen av sitt liv, menade att "det lärda och skapande intellektuella livet är ett sätt att leva, inte någon handelsvara". ${ }^{163}$ Visst var det universitetens uppgift att förmedla information men att förmedla den genom ett skapande intellekt, det som han kallar imagination, ett ord som här inte rakt av kan översättas med "fantasi". Whitehead var en av det tidiga 1900-talets stora intellektuella i den engelsktalande världen; han undervisade filosofen Bertrand Russell och skrev ett av århundradets viktigaste matematiska verk, Principia Mathematica, tillsammans med honom. När han snart skulle fylla sjuttio flyttade han från Cambridge och London till Harvard och började en ny karriär, bland annat med att skriva en samling uppsatser om utbildningens och i synnerhet den högre utbildningens mål. Universitets uppgift, skriver Whitehead, är att svetsa samman erfarenhet med skapande intellekt, imagination and experience. Universitetet förmedlar information men förmedlar den genom ett skapande intellekt - också med fantasi, om man vill. Han har i samma uppsats några uppmaningar till universitetsledningar: om man vill att lärarna ska bli skapande intellektuella (imaginative) ska de uppmuntras att forska; om man vill att forskarna ska bli skapande intellektuella (imaginative), ska man se till att de kommer i kontakt med unga människor när de är som mest entusiastiska och skapande. Ett annat råd han ger i uppsatsen är att det vore ett stort misstag (the greatest mistake) att bedöma lärarna utifrån vad de publicerat. Enkla råd om områden där åtminstone den svenska högskolan under decennier utvecklats åt motsatt håll: lärare har fått allt mindre tid att forska medan allt större tyngd läggs vid publiceringar. Ett sista råd från Whitehead, ännu ett som inte hörsammats men som förtjänar att upprepas: "universitet kan inte behandlas enligt samma regler och policys som gäller för vanliga affärsföretag". ${ }^{164}$

163 "The learned and imaginative life is a a way of living, and is not an article of commerce." Whitehead 1929, s 97.

164 "... remember that universities cannot be dealt with according to the rules and policies which apply to familiar business corporations" (Ibid s 100) 
Flera tror dock att en alltmer välfungerande marknadsstruktur för den högre utbildningen kommer att ha ett avgörande inflytande på hela utbildningssystemet. Högskoledebattören Ben Wildavsky tror att frihandel inom akademin, där studenter väljer efter global brand och väljs efter en sann meritokrati, för med sig stora fördelar och "i förlängningen återställer global välfärd". ${ }^{165}$ Walter McMahon, som jag nämnt tidigare, ser brister i faktaunderlag och tillgång till information om den högre utbildningens fördelar för individer och länder som det främsta hindret för en välfungerande marknad. En tredje nordamerikansk högskoledebattör, Henry Giroux, skräder å andra sidan inte orden i sitt fördömande av hur vad han kallar "kasinokapitalismen" når allt djupare in i samhällslivet:

En etik som bygger på den starkastes överlevnad och vars mantra om att göra nästan vad som helst för att öka vinsterna, numera genomsyrar alla aspekter av samhället och sprids vitt och brett som en slags folklig pedagogik genom de dominerande nya medierna. ${ }^{166}$

Och vi inom akademin hjälper till:

Marknadsdrivna värderingar, kultur och pedagogik erbjuder en ny förståelse av medborgaren som konsument, universitetet som gisslan hos företagskulturens oböjliga befallningar och den akademiska arbetskraften (labor) som en ny klass av fänrikar (subalterns) upptagna av att producera nästa generation nyliberala undersåtar. ${ }^{167}$

Citatet tål att läsas om. Det är en uppskruvad retorik, förstås, men den rymmer några uppfordrande anspelningar som åtminstone bör begrundas innan de möjligen avfärdas. Först finns en anspelning på Hanna Arendts begrepp labor, work och action, där labor står för det oreflekterade arbetet, nödvändigt för livsuppehället men som lämnar inget bestående kvar efter sig. ${ }^{168}$ Lärare inom akademin är i Giroux föreställning trälar i kapitalets våld där vi lydigt kämpar för en allt bättre anställningsbarhet för våra studenter. Men vi är inte bara trälar,

165 "... which is why free-trade in minds holds the key to sustaining the world's knowledge economy and ultimately to restoring global prosperity." (Wildavsky 2010, s 193)

166 "The survival of the fittest ethic and its mantra of doing just about anything to increase profits now reach into every aspect of society and are widely dispersed as a form of public pedagogy in the dominant and new media" (Giroux 2012, s 41)

167 "Market-driven values, culture, and pedagogy offer up a new understanding of the citizen as consumer, the university as hostage to the imperatives of business culture, and academic labor as a new subaltern class engaged in the production of the next generation of neoliberal subjects." (Ibid, s 127)

168 "It is indeed the mark of all laboring that it leaves nothing behind, that the result of its effort is almost as quickly consumed as the effort is spent. And yet this effort, despite its futility, is born of great urgency and motivated by a more powerful drive than anything else, because life itself depends on it." (Arendt 1958, s 87) 
vi är också subalterns, bokstavligen fänrikar, den lägsta graden i den militära officershierarkin; till och med våra tankar har koloniserats av en namnlös makt så till den grad att vi utan minsta ifrågasättande driver våra meniga soldater studenterna - framför oss mot framtida segrar för profiten. ${ }^{169}$ Om det inte är så - för det är det väl inte? - hoppas jag innerligen att vi kan hitta och sprida goda exempel och motargument, som istället visar att vi arbetar för att uppnå vår högskolelags stolta mål om studenters förmåga att göra självständiga och kritiska bedömningar och högskolornas skyldighet att främja ekonomisk och social välfärd och rättvisa.

\section{Där skall vara gråt och tandagnisslan}

Tveklöst gagnar den globala konkurrensen de globala vinnarna, de som hamnar på topplatserna i världsrankningen. Men hur gagnar den de övriga 99,9 procenten bland världens lärosäten? Huvudargumentet, oftast underförstått och taget för så självklart att det sällan uttalas, är att jakten på excellens kommer att smitta av sig. Excellens kommer att sippra ner genom lagren av halvdana institutioner världen över och höja den generella kvaliteten. Då slås de dåliga ut och försvinner. Genom att alla kämpar för att nå toppen kommer kvaliteten hos alla att bli bättre. Men finns det något bevis, eller ens något tecken på att det är så? Kan inte resultatet bli lika förödande som för skoleleven som trots idogt arbete får det lägsta eller näst lägsta betyget? Och i vissa system, bland andra det svenska, spär man på effekten genom att ge dem som inte når toppbetyget mindre pengar. Alla betygssystem är relativa, alla kan inte få en femma, hur ofta man än försöker bevisa motsatsen med målrelatering och annat, vare sig det gäller svenska skolelever eller världens akademier. Och excellens är ett relativt begrepp, själva ordet innebär att resa sig över något lägre. Och då måste man vara väldigt klar över vad verksamheten syftar till och vad det innebär att vara bra i det. Det är fara värt att det också leder till en likriktning i vad Sven-Eric Liedman i en träffande fras har kallat "det utmärkt normala". ${ }^{170}$ Att publicera sig i ett fåtal ledande tidskrifter, som visserligen läses av många eller i ett otal andra som läses av få eller inga, kan inte rimligen vara verksamhetens mål. Och det är förstås ingen vettig forskare som tror det heller, men man beter sig som om det vore det och hela systemet beter sig som om det vore det.

Jag har inte hittills sett någon studie som försöker gå till botten med fördelar och nackdelar med ett konkurrensbaserat system och en fingerad marknad för högre utbildning. För ett fåtal är kanske den kortsiktiga effekten positiv, men ser man till hur mycket hela den högre utbildningen och hela samhället vinner

${ }_{169}$ Ordet rymmer också en tydlig anspelning på postkolonialistisk teori och kulturanalys där $s u b$ altern syftar på den "orientaliska" underklassen som har koloniserats av västerländsk kultur och värderingar och som inte har rätt att uttala sig. Se t.ex. Gayatri Chakravorty Spivaks "Can the Subaltern Speak?" (1988)

${ }^{170}$ Liedman 2011, s 163. 
på konkurrensen om studenter, lärare och resurser, håller jag för troligt att samarbete mellan lärosäten leder till flera fördelar för flera människor.

Som jag nämnt tidigare, verkar också den knivskarpa konkurrensen som gäller för att få publicera sin forskning i ledande tidskrifter både konserverande och inåtblickande. Det konserverande finns i hela belöningssystemet där karriären både för individen och för lärosätet bygger på prestigefyllda publiceringar och den därmed sammanhängande forskningsfinansieringen. Matteus-effekten är tydlig: "Var och en som har, han skall få, och det i överflöd", står det i Matteusevangeliet 25:29. Det är som att den gud som designat högskolesystemet skulle ha bestämt sig för att detta ska vara den grundläggande principen för alla världens högskolesystem, både i forskning och utbildning. I forskningen är den särskilt uppenbar där de framgångsrika tilldelas enorma summor forskningsmedel, ibland så mycket att de inte hinner eller förmår bruka dem. I Sverige bär Lunds universitet syn för sägen med jättelika ansamlingar outnyttjade forskningspengar begravda overksamma i myndighetskapitalet - 2013 hade 1,6 miljarder kronor samlats där, förutom ytterligare oförbrukade forskningsmedel på 2,5 miljarder. ${ }^{171} \mathrm{Om}$ man räknar med att en forskare kostar kanske en miljon om året, finns där 4000 forskarår outnyttjade. Det är tydligen inte för inte att själva begreppet Matteus-effekt användes för första gången just om den naturvetenskapliga forskningen, då av sociologen Robert Merton 1968 i en artikel i tidskriften Science. ${ }^{172}$ Där är hans huvudpoäng att det är de kända forskarnas bidrag som räknas, trots att det ofta är mindre kända forskare som gjort arbetet. Inte nog med de fördärvliga finansiella effekterna, vetenskapen har sin egen kändiskult också, där de kända spelarna byter lärosäte för mångmiljonbelopp, precis som i Champions League. Skillnaden är bara att forskarna inte behöver fortsätta göra målen själva, bara deras namn är med i laguppställningen.

Kändiskulten i sig verkar konserverande, det blir ett slags gerontokrati, där de äldsta styr i kraft av sina namn. Men kollegagranskningen, den så omhuldade peer review, har också en inneboende konservativ och nivellerande effekt. Kollegorna måste komma överens om vad som passar i en viss tidskrift, vad som är tillåtet inom gränserna för en viss disciplin, och vad som kan bedömas som god forskning inom den disciplinen. Samma sak gäller i högskolornas anställningar, docentmeriteringar, professorstillsättningar och numera även kvalitetsutvärderingar. I det här sammanhanget kan det vara nyttigt att påminna om den kritik som en gång riktats mot den "nästintill heliga kollegagranskningen" av en av dess främsta användare, redaktören för den anrika medicintidskriften The Lancet: "Vi vet", skrev han, "att peer-review-systemet är subjektivt, orättvist, ogenomskinligt, ofullständigt, lättriggat, ofta förolämpande,

171 Uppgifterna är hämtade ur Lunds universitets magasin, LUM i februari 2013 http://www4. lu.se/o.o.i.s?id=12344\&news_item=9059 2013-12-01. Där säger för övrigt planeringschefen Tim Ekberg att det är "samma forskargrupper som får de stora anslagen vilket innebär att forskningen styrs mot de områdena. De rika blir rikare och de fattiga fattigare."

172 Merton 1968. 
vanligen okunnigt, ibland dumt och vid många tillfällen har helt fel., ${ }^{173}$ Men även om man accepterar att systemet för närvarande är det bästa som finns, måste kollegorna i vart fall ange råmärken för just den eller den vetenskapliga disciplinen. Det verkar inte precis vara rätt grogrund och näringsmedel för mångdisciplinära forskningsansatser som riktar in sig mot samhällets nästan alltid mångdisciplinära problem. Den som ändå skriver eller talar om sådana problem får visserligen inkludera bidragen i sitt $\mathrm{CV}$ med då under den betydligt mindre viktiga rubriken "populärvetenskapliga bidrag". I Universitetskanslersämbetets senaste utvärderingar har troligen den mest centrala frågan varit vad det är som utgör essensen i ett ämne eller, i nyare jargong, huvudområde. Studenternas examensarbeten har bedömts i relation till hur väl de visar att de behärskar ett ämnes teorier och metoder; dess kärna, brukar det kallas. Inte det enda kriteriet men bevisligen det tyngsta, om man läser bedömargruppernas uttalanden. Kvaliteten i hela utbildningen bedöms sedan utifrån hur stor andel av uppsatserna når upp till detta av kollegorna uppsatta mål. Sedan får de som når upp mera pengar, de som inte når upp mindre pengar. "Var och en som har, han skall få och i överflöd", löd Matteuscitatet. Det fortsätter: "men den som inte har, från honom skall tas också det han har". Fortsättningen kommer i nästa vers, nu i 1917-års bibelöversättning: "Och kasten den oduglige tjänaren ut i mörkret härutanför. Där skall vara gråt och tandagnisslan." (Matt 25:30)

Det finns mångdisciplinära utbildningsmiljöer som klarat sig bra men de hör till undantagen och de premieras definitivt inte av systemet. Det finns också motreaktioner i form av flervetenskapliga tidskrifter och forskningsområden men den grundläggande driften tycks vara i riktning emot de allt finare och mer specialiserade kapillärerna. Problemet är bara att blodomloppet oftast tycks ha koagulerat - det finns inget flöde mellan de fina kapillärerna och framförallt ett mycket trögt flöde tillbaka till hjärtat av mänsklighetens problem. Ju större människans samlade vetande blir, desto trängre blir kapillärkärlen

Jag misstänker att hela rankningshysterin - och det är verkligen en hysterisk jakt på poäng bland världens mest respekterade lärosäten - bygger på en enkel medielogik. Det är inte bara de populäraste tidningarna som med förkärlek trycker listor över vem som tjänar mest eller de bästa vinsorterna eller de fem mest populära killarna i klassen. I en marknad där ryktet och varumärket betyder allt, blir rankinglistan ett av de viktigaste sätten att synas. Logiken och dess följder har inte bara svalts med hull och hår av akademin själv utan också av - och kanske framförallt av - politiker i alla läger. Det blir en högt prioriterad nationell angelägenhet att se till att de egna lärosätena stiger uppåt i rankingen och att landet har åtminstone några med riktiga toppnoteringar när

173 "The mistake, of course, is to have thought that peer review was any more than a crude means of discovering the acceptability - not the validity - of a new finding. Editors and scientists alike insist on the pivotal importance of peer review. We portray peer review to the public as a quasi-sacred process that helps to make science our most objective truth teller. But we know that the system of peer review is biased, unjust, unaccountable, incomplete, easily fixed, often insulting, usually ignorant, occasionally foolish, and frequently wrong." (Horton 2000) 
Shanghai Jiaotong eller The Times publicerar sin senaste lista. Det är underförstått att framgång för ett annat land på något sätt förminskar det egna landets forsknings- eller utbildningsprestationer, inte, som det troligen gör tack vare akademisk öppenhet och samarbete, främjar dem.

Konkurrens som motor på högskolornas marknad skapar alltså en del problem. Ett annat stort problem med företagsanalogin är just svårigheten att identifiera produkten av högskolans verksamhet och den ännu större svårigheten att identifiera en kvantifierbar produkt. I tillverkningsindustrin är det enkelt förstås. Bilar går att räkna och kvaliteten går att mäta i kundnöjdhet och felfrekvens. Även serviceföretag kan mäta sin framgång i antalet nöjda kunder och stigande vinster som kan delas ut till ägarna. Men, som jag varit inne på under ett tidigare avsnitt, högskolans produkt är framförallt dess process. Och den processen handlar framförallt om olika former av samarbete, samarbete mellan forskare, samarbete mellan lärare och studenter, samarbete mellan studenter. Eftersom produkten är processen blir det lätt vilseledande att se studenten som en kund. Detta innebär inte att sådant som utvecklats inom företagsvärlden inte skulle kunna utnyttjas inom högskolan. Där finns mängder med goda exempel att hämta på hur man kan hushålla med resurser, driva utveckling och främja kvalitet. Men de måste alla anpassas till den speciella situationen det innebär att det inte är produkten som räknas, utan processen, och att det inte är konkurrens som är drivmedlet utan samarbete.

\section{Plikten och profiten}

Den högre utbildningen har alltså ännu inte privatiserats i Sverige. På ett sätt är det märkligt att inte högskolan var ett av de första föremålen för utförsäljning av staten under den privatiseringsvåg som svepte över landet när vården, skolan och omsorgen blev möjliga att driva i privat regi. Hur viktig man än tycker den är för ett samhälle, utgör inte den högre utbildningen ett lika grundläggande samhällsfundament som att ta hand om våra sjuka och gamla eller att fostra våra barn. Varje samhälle sedan mänsklighetens gryning har haft någon form av organisation för dessa båda funktioner och om ett system fallerar, så har man varit tvungen att uppfinna ett annat. Plikten och samvetet, det vetandet som vi har samman med alla andra och med andra generationer, kräver det. Fram till 1800- och 1900-talens framväxande välfärdssamhällen har familjen och släkten varit den främsta säkerheten och tryggheten för barnen, för sjuka och för gamla. För att kunna garantera en minimistandard för alla och för att möjliggöra för alla, både kvinnor och män, att delta i arbetslivet och produktionen utanför hemmet, har det offentliga, i form av stat och kommun, alltmer trätt in som den självklara anordnaren av barnomsorg, skola, sjukvård och äldreomsorg. Men från 1980-talet och framåt har en allt större del av sådan verksamhet i Sverige inlemmats i marknaden genom att överlåtas till vinstdrivande företag. Bakgrunden till den förändringen i samhällsklimat och allmän opinion 
som ledde fram till en sådan fullständig U-sväng $\mathrm{i}$ hur vi sköter våra grundläggande mellanmänskliga åtaganden är värd att begrunda en stund, inte minst eftersom den också belyser många av de strömningar i New Public Management som också i högsta grad påverkat högskolorna de senaste decennierna.

I en omfångsrik och uppslagsrik essä från 2004 försöker Göran Rosenberg ringa in vad som hänt. Han kallar sin upprörda idéhistoriska exposé för Plikten, profiten och konsten att vara människa och anger redan i titeln huvudlinjerna i sitt resonemang. "Plikter", skriver Rosenberg, "är vad som får människan att slå vakt om de långsiktiga förutsättningarna för sin egen existens", ${ }^{174}$ det vill säga att bidra till den väv av mellanmänskliga åtaganden över generationer som inte omedelbart gagnar en själv men utan vilka det samhälle som vi lever av och i skulle varje omöjligt att upprätthålla. Vi bryr oss inte bara om våra släktingar och grannar utan också via skattefinansierad vård och omsorg även om alla andra människor i samhället. Vi gör det därför att vi själva vill leva i ett sådant samhälle där inte bara vi själva, som kanske samlat tillräckligt med pengar under våra liv för att bekosta en värdig ålderdom, utan även alla andra får åldras med värdighet.

Profiten i Rosenbergs framställning ska förstås inte bara som vinsten från ett företags verksamhet utan som allt som bidrar till att göra ens eget liv bättre, omedelbart eller inom en överskådlig framtid. Men det är inte så att plikten är det goda och profiten det onda. "Profiten är en lika nödvändig drivkraft hos människan som plikten", skriver Rosenberg. ${ }^{175}$ Profiten är också en förutsättning för plikten. Man måste kunna föreställa sig ett gott liv för sig själv om man ska kunna bidra till ett gott liv för andra. Barnets själviska sökande efter egna fördelar utgör en del av den långa processen att bli en självständig individ. Den vuxnas drivkraft att göra livet bättre för sig och de sina bidrar ofta till hela samhällets utveckling. Konsten att vara människa ligger att rätt kunna balansera plikten och profiten, att se och förstå "en möjlig frihet i ett ofrånkomligt beroende". ${ }^{176}$

Men det finns också en föreställning, som Rosenberg spårar, om att profitjakten i sig är tillräcklig, att människor genom sina själviska, profitdrivna handlingar kommer att skapa de institutioner som behövs för ett välfungerande samhälle. Redan tidigt på 1700-talet, då Europas moderna marknadssamhälle fortfarande höll på att växa fram ur medeltidens mer statiska feodalsamhälle, skrev en holländsk läkare verksam i England, Bernard Mandeville, en verssatir med titeln The Fable of the Bees. Man ska förstå att det är England han beskriver med sitt bisamhälle. Så länge bina sköter sina själviska göromål så fungerar samhället, men den dagen de blir dygdiga och slutar söka efter egen vinning, rasar ekonomin och samhället ihop. Människans laster, genom att de kräver konsumtion av olika slag, utgör i själva verket grunden för hela ekonomin. Idén

\footnotetext{
174 Rosenberg 2013, s 81.

175 Ibid, s 136.

176 Ibid, s 172.
} 
verkar inte alldeles främmande i vår tid, men då blev hans tankar föremål för mycket offentlig kritik och till och med ett åtal. I Mandevilles värld är ett välfungerande samhälle också beroende av en stor och förnöjsam arbetarklass, som inte gör anspråk på ett bättre liv. Välgörenhetsskolorna som började växa upp för att lära de fattiga ett moraliskt sunt leverne, motsatte sig förstås Mandeville. Det är inte utan att man ser en parallell i vår tid där också och kan undra om en del av motståndet mot en universell högre utbildning bottnar i en djupt sittande men onämnbar övertygelse om att det måste finnas en obildad och okritisk underklass som med sina laster kan hålla ekonomin igång och förse den växande medelklassen med billiga tjänster.

Mandevilles teorier om att egenintressets krafter inte bara är välgörande utan i sig tillräckliga för samhällsinstitutionernas utveckling har fătt en renässans, menar Rosenberg, i Thatcher och Reagans 80- och 90-tal. Då växte det snabbt fram en vida spridd övertygelse om att egenintresse, marknadskrafter och profiter ger större frihet och bättre kvalitet i alla former av samhällsinstitutioner, däribland skola, vård och omsorg.

Det var staten som i hög grad hade tagit över ansvaret för välfärden från familjens godtycke och osäkra resurser, tidigast kanske i Storbritanniens Welfare State som efter andra världskrigets outsägliga fasor skulle bygga upp ett gott och tillitsfullt samhälle. Socialdemokratin i Sverige hade råd att bygga ännu tätare skyddsnät medan i USA förblev det statliga skyddsnätet rudimentärt och betraktat med allt större skepsis, mer eller mindre som ett utslag av kommunistisk infiltration. Så länge folk kom ihåg 30-talets depressioner, och så länge de nationella ekonomiska styrsystemen kunde ses fungera, stod dock västvärldens demokratier fast vid att utveckla ett offentligt finansierat och drivet välfärdssystem. Men när världsekonomin, inte minst tack vare de momentana digitala kommunikationerna och kapitalflödena, växte utanför nationell kontroll, då var och en påstods kunna skapa sig en förmögenhet genom aktieköp och börsklippen kunna bli var mans möjlighet, var det läge att återigen ifrågasätta the nanny state, som fråntog individen ansvaret för sitt eget liv

Rosenberg menar också att de sista trettio årens privatiseringar, marknadifiering och liknande samhällstendenser bygger på "föreställningar om att friheten går före beroendet (och individen före samhället) [som] tenderar att växa sig starka i tider då samhällsordningen förlorar sin trovärdighet och banden mellan individ och samhälle försvagas.” ${ }^{177}$ Och det är väl här som ett svar möjligen kan börja skönjas på frågan varför - och varför just under vår tid. Rosenberg menar att vår egen tid präglas av brytningen "mellan en territoriellt avgränsad och platsbunden samhällsordning och territoriellt flytande ekonomiska och politiska ordning som vi ännu inte kan se konturerna av och ännu inte känner oss bundna till', ${ }^{178}$ det vill säga, om jag tolkar honom rätt, maktlösa nationella

177 Ibid, s 148.

178 Ibid. 
styresskick i en globaliserad industriell konsumtionsekonomi. Jag kan tycka att just de orsakssamband som Rosenberg pekar på här har något av ett cirkelresonemang över sig: individens ansvar för det allmänna minskar därför att banden mellan individen och det allmänna försvagas.

Den engelska historikern Tony Judt har i sin skildring av de socialdemokratiska idealens fall, Illa far landet, en annan förklaring till varför det under loppet av ett årtionde blev acceptabelt, till och med önskvärt, för staten att överlämna sitt ansvar för olika former av gemensamma samhällsinstitutioner till privata företag. Judt menar att både i stora delar av Europa och i USA hade de konservativa högerideologierna förlorat all trovärdighet före och under andra världskriget. Den fria marknaden hade lett till en långvarig ekonomisk depression med förfärliga sociala följder och de konservativa eliterna, både i Frankrike och ett antal andra europeiska länder, hade anpassat sig väl lätt till ockupationsmakterna. Det blev en slags socialdemokratisk konsensus i stora delar av västvärlden och en allmän uppslutning bakom Keynes idéer om statens roll som garant för social trygghet och mot kapitalismens ytterligheter vad gäller fördelning av välstånd. Men tre decenniers konsensus bar också inom sig fröet till sin egen nedgång. Ju fler som glömde eller inte hade upplevt 30-och 40-talets katastrofer, desto bättre grogrund för konservativt motstånd mot å ena sidan studentuppror och hippie-kultur, och å andra sidan makttunga fackföreningar och stelbent statsbyråkrati. "Under loppet av lite mer än tio år", skriver Judt, "skiftade det dominerande mönstret för det offentliga samtalet från entusiasm för en ingripande politik och strävan mot det allmännas väl till en syn på världen som bäst sammanfattas i Margaret Thatchers 'kvickhet': 'Det finns inget sådant som ett samhälle, det finns bara individer och familjer.' I USA vann Ronald Reagan, vid nästan exakt samma tid, en bestående popularitet för sitt anspråksfulla yttrande att det var 'gryning i Amerika'. Staten var inte längre lösningen, den var problemet." ${ }^{\text {"19 }}$

Och då, vid 1980-talets början, fanns nationalekonomerna vid Chicago-universitetet, anförda av Milton Friedman, till hands med sina ideal om minsta möjliga statliga inblandning och största möjliga frihet för den individuella entreprenören. Där fanns också ekonomen Arthur Laffer, som med en enkel kurva visade att ordentligt skattesänkningar för de rika kommer att ge mera, inte mindre pengar till staten. Teorin bygger på tanken att ju mindre skatt folk betalar, desto mera angelägna är de att arbeta och därmed bidra till ökade inkomster, såväl för dem själva som för staten. Och det var en teori som fick ett enormt genomslag, inte minst genom George Gilders Wealth and Poverty som kom ut 1981 och sålde i över en miljon exemplar. På de trettio åren som gått sedan dess har Laffers kurva förmodligen starkt bidragit till de dramatiskt ökande inkomstklyftorna, inte bara i USA utan i stort sett i hela västvärlden, samma klyftor som Wilkinson och Pickett beskriver följderna av i Jämlikhetsanden. Tankegången beskrivs på ett slagfärdigt sätt av ekonomen Katrine

179 Judt 2010, s 89. 
Kielos så här: "Att sänka skatten för de rika är det bästa vi kan göra för de fattiga: Får de rika mer pengar i plånboken kommer de att starta företag, investera i ny teknik och därmed sätta fart på tillväxten, menade Gilder. Jobben kommer att bli fler och personer som tidigare varit arbetslösa kommer att börja jobba i företagen som de rika startar. De kommer att få lön och på den lönen kommer de att betala skatt. Då kommer även statens intäkter att öka. Staten får alltså igen pengarna som den precis sänkt skatten för. Ett minus ett är inte längre noll. Det var trolleri och för bra för att vara sant. Till och med George Bush den äldre kallade teorierna för "voodoo-ekonomi". Vilket de naturligtvis var." 180

Tony Judt gör också ett spännande tillägg till vad som annars kanske är en bekant historieskrivning. Han menar att de idéer som Thatcher och Reagan hämtar från Chicago ursprungligen kom från en grupp österrikiska tänkare och skribenter som flydde hemlandet från nazisterna till England och USA: Joseph Schumpeter, känd som entreprenörskapets främsta banérförare; Friedrich Hayek, främst bland klassiska liberala ekonomer under och efter andra världskriget; och inte minst Karl Popper, vetenskapsfilosof som jag tidigare refererat till flera gånger när det gäller grunden för vetenskaplig kunskap. Alla var de på olika sätt övertygade om att det var misslyckade försök till en socialistisk politik i Österrike under mellankrigstiden som ledde till en motreaktion i form av statskuppen 1934 och sedan den nazistiska invasionen. Inte minst Popper pläderade med en blytung intellektuell och idéhistorisk argumentering för faran i tron på en "historisk nödvändighet" av marxistiskt snitt och framförallt för varje tendens i riktning mot ett totalitärt samhälle, vare sig av Platons, Hitlers eller Stalins snitt. De två volymerna som utgör Det öppna samhället och dess fiender, utkom i England, betecknande nog, vid krigsslutet 1945. Det kanske är lika betecknande att det var just 1979 som jag ägnade en stor del av min egen tid åt att översätta Poppers verk till svenska på en liten Olivetti i en studentlägenhet. Då behövde jag pengarna och njöt av den övermaga utmaningen. $\mathrm{Nu}$ förstår jag att också jag utgjorde en liten del i en ideologisk samhällsomvandling som höll på att växa fram i mitt hemland och USA för att obönhörligen exporteras till resten av västvärlden - och inte, som bekant, bara västvärlden.

När tiden var mogen fanns ideologierna alltså till hands. Det var ideologier som hade vuxit fram ur en reaktion hos tänkare födda på 1800-talet mot händelser i deras hemland över femtio år innan deras teorier vann världsomfattande gehör. Tron på Keynes ekonomiska strategier för att avvärja kapitalismens värsta cykliska effekter och tron på staten som de svagas försvarare var som bortblåsta, trots att hans strategier legat bakom vad som troligen var de mest fredliga, ekonomiskt expansiva och socialt utjämnande årtionden i västerlandets historia - från ungefär 1950 till 1980. Les trente glorieuses kallar fransmännen åren för. ${ }^{181}$

\footnotetext{
180 Kielos 2012, s182f.

181 "De strålande trettio" - det franska utrrycket myntades av demografen Jean Fourastié och syftade egentligen på åren 1945-75 då produktiviteten, löneförhöjningar och förbättringar i det sociala skyddsnätet var rekordhöga i Frankrike.
} 
Utvecklingen var förstås i verkligheten långt mera komplex och motsägelsefull än jag kunnat redogöra för här. Rosenberg pekar också till exempel på betydelsen av de biologiska förklaringsmodellerna som lanserades ungefär samtidigt. Richard Dawkins The Selfish Gene kom 1976 och Trivers skrev om reciprok altruism några år tidigare. Båda teorier kunde användas för att förklara hur i förlängningen självintresset kunde bygga, i analogi med Adam Smiths osynliga hand, till synes oegennyttiga samhällsinstitutioner. Men, som Rosenberg också påpekar, människor är inte bara kapabla att bygga upp samhällen, de är också benägna att förstöra dem. Kvar finns ett val mellan plikt och profit i varje enskilt fall och de bör inte sammanblandas. Vissa verksamheter ska byggas utifrån ett moralsystem grundat på plikten - däribland naturligtvis skolan, vården och omsorgen - medan andra ska byggas på en profitmoral, handel med varor till exempel. Om man blandar ihop de två, uppstår samhälleliga monster, skriver den amerikanska stadsforskaren Jane Jacobs, som Rosenberg har hämtat inspiration från. ${ }^{182}$ Kan man sälja och köpa våld och straff blir resultatet en maffia. Om staten driver handel kan det uppstå ett samhälle med allt det förtryck och ofrihet som den statskapitalistiska kommunismen i Sovjet innebar.

Jag har ägnat en del utrymme åt att försöka förstå förändringarna i idéklimatet som ligger bakom marknadsidealets framväxt inom samhällsinstitutioner som tidigare ansågs självklart tillhöra pliktsfären, därför att det ger en så viktig bakgrund till den högre utbildningens prekära dilemma idag. Ännu har inte högskolan privatiserats, skrev jag, och antydde därmed att det nog inte är ett alltför avlägset framtidsscenario. Men redan nu drivs högskolan som vore det en del av profitsfären och inte pliktsfären. Eller snarare kanske det är så att vi inom den högre utbildningen oroligt hoppar från det ena benet till det andra; vi konkurrerar med andra högskolor enligt profitmoralen och samarbetar med dem enligt pliktmoralen. Vi är ålagda att vara alltmer effektiva och sparsamma med resurser, såsom profitmoralens cost-benefit-analys påbjuder, samtidigt som vårt uppdrag gentemot studenter kräver empati och generositet med tid. Och för att de ansvariga, akademins ägare, ska kunna visa att vi blir mer effektiva måste mätbara mål utarbetas och nya rutiner införas för att säkra den mätbara kvaliteten. För att se vilka effekter - säkert ibland oavsiktliga - sådana ambitioner kan få, kommer jag nu att ägna två principer åt den högre utbildningens inre arbete, det som sker utanför själva undervisningen och forskningen i form av kvalitetskontroll och byråkrati.

${ }^{182}$ Jane Jacobs skrev Systems of Survival: a dialogue on the moral foundations of commerce and politics (översatt till svenska som Morallära för 2000-talet) utifrån en platonsk disktinktion mellan handlarnas moral och väktarnas moral. Rosenberg utvecklar åtskillnaden vidare i en uppställning där han kontrasterar profitmoralens och pliktmoralens nyckelbegrepp (s 190-191). 